http://dx.doi.org/10.12795/PH.1991.v06.i01.02

\title{
La función del agua en los cuentos de El llano en llamas de Juan Rulfo
}

Angel Sánchez-Escobar

\section{Introducción}

Elpropósito de estas páginas es definir un eje unificador de la obra literaria de Juan Rulfo, y en especial de su libro de cuento El llano en llamas (1955); obra de gran relevancia porque en ella convergen contenido, lenguaje y técnica de la narrativa hispano americana en general.

Este elemento unificador se encuentra adscrito en la manera tan singular de interpretar y describir la realidad del paisaje mexicano y la del hombre inmerso en el mismo. Rulfo presenta un paisaje condicionante, como un fuerza contra la que el hombre ha de enfrentarse constantemente para sobrevivir. Enfrentamiento en el que el hombre aparece «fundido» con los elementos físicos que le rodean en un intento frustrado de encontrar una realización que se presenta imposible, o un escape de la soledad y de la muerte. Rulfo, como nos dice Walter M. Langford, «is obssesed with death, both of the land and of the people on it» ${ }^{1}$.

La presentación en toda su adversidad de estos elementos físicos, ocasiona en los cuentos de El llano en llamas la configuración del hombre como una modulación de la realidad exterior; a su vez, en Pedro Páramo, «se lleva hasta sus formas más extremas la fusión del hombre con las sustancias cósmicas»².

Dentro de estos elementos físicos, el agua aparece como uno de los más trascendentales por ser, en su variedad de funciones y formas, un determinante común en la mayoría de los cuentos y en Pedro Páramo, y por adquirir un papel importante en la caracterización de mucho de los personajes creados por Rulfo.

\footnotetext{
${ }^{1}$ Walter M. Langford, The Mexican Novel Comes of Age (Indiana: University of Notre Dame Press, 1971), p. 89.

${ }^{2}$ Enrique Pupo-Walker, «Personajes y ambiente en Pedro Páramo», Cuadernos americanos 6 (Noviembre-Diciembre, 1969), p. 199.
} 
$\mathrm{El}$ agua entra a formar parte del paisaje tanto en ausencia como en presencia, creando en los cuentos un entorno físico que nos hace clasificarlos en dos tipos diferentes, dependiendo de la presencia o escasez de este elemento tan preciado para el hombre nacido y criado en contacto directo con la tierra. Sin embargo, no solamente la escasez de agua perjudica a la tierra y condiciona al campesino, sino que el agua, cuando aparece, lo hace de tal forma y circunstancias que tampoco lo beneficia.

Pero además de esta función condicionante del agua que sería fácilmente observable en un nivel literal, existen otras funciones que nacen en un nivel contextual y que manifiestan, de igual manera, la gran capacidad artística de Rulfo. Estas funciones son, entre otras, la irónica, contrastiva, simbólica, metafórica, evocativa, etc., que dotan al texto de una gran riqueza de expresión.

No existe, pues, futuro en el mundo descrito por Rulfo. «El tiempo se cierra en toda la obra de Rulfo. El futuro está herméticamente sellado. Sólo queda el presente. En ello reside la hondísima tristeza de los cuentos de Rulfo; y en ello también su fatalismo» ${ }^{3}$.

Fatalismo y ensimismamiento que caracterizan a cada uno de los personajes y que les hace hundirse en un mundo interior desde el que nos llega cada uno de sus pensamiento y actos.

Pero Juan Rulfo, como menciona Blanco Aguinaga, hace algo más, lleva unos elementos locales a un nivel trascendental y de validez universal:

Rulfo' trae a la prosa mexicana esta subjetividad contemporánea, la angustia del hombre moderno que se siente nacido de la tierra, de un rincón concretísimo de tierra (Dublín, Alabama, Jalisco), y que quisiera agarrarse a ella mientras todo se desmorona por dentro: la agonfa -ya puramente contemplativa- del solitario sin fe para quien todas las cosas que le rodean son símbolos mudos ${ }^{4}$.

Y efectivamente, la postura del hombre ante la angustia y el sufrimiento adquiere en los cuentos de El llano en llamas un sentido que sobrepasa lo puramente localista y particular. Sentido que Rulfo llevará también a las líneas de Pedro Páramo.

Así pues, en este estudio enfocaré la relación hombre-paisaje, poniendo especial énfasis en la función del agua. Función que, como ya he dicho, va desde un sentido literal, inmiscuyéndose en la vida del hombre -ocasionándole la desesperación y la muerte- hasta un sentido poético y su transformación metafórica en los sueños de amor perdido del cacique Pedro Páramo.

\footnotetext{
${ }^{3}$ Ramón Xirau, «Crisis del realismo», en América Latina en su Literatura, ed. César Femández Moreno (México: Siglo XXI, 1978), p. 200.

${ }^{4}$ Carlos Blanco Aguinaga, «Realidad y estilo de Juan Rulfo», en Nueva Novels Latinoamericana, ed. Jorge Lafforte (Buenos Aires: Editorial Paidos, 1969), pp. 86-87.
} 


\section{Abundancia de agua: «es que somos muy pobres», «la cuesta de las comadres», «el hombre» y «Paso del norte»}

«Es que somos muy pobres» nos es trasmitido por un narrador-personaje mediante un monólogo. Aquí la dependencia del hombre al ganado adquiere notas de gran dramatismo porque la pérdida de éste no sólo acarrea una ruina económica sino moral al mismo tiempo 5 .

El agua en forma de lluvia y río embravecido destruye en primer lugar la cosecha de cebada: «Y el aguacero llegó de repente, en grandes olas de agua, sin damos tiempo siquiera a esconder aunque fuera un manojo " ${ }^{6}$. Y se lleva también a la Serpentina, la vaca que el padre le había regalado a Tacha por lo «que puede sucederle el día de mañana» ${ }^{7}$. Esta vaca era la única posibilidad de que Tacha pudiese encontrar un marido y «no se fuera a hacer de piruja» ${ }^{8}$ como hicieron sus hermanas mayores. La única esperanza que queda es que el becerro no se lo hubiese llevado también la corriente porque si así ha sido, Tacha, como nos dice el narrador, «está así de retirado de hacerse piruja» ${ }^{9}$.

$\mathrm{El}$ agua tiene aquí un doble funcionamiento literal-simbólico que entra a formar parte de la doble consecuencia económico-moral que engendra. Por un lado tenemos la descripción literal del río así como sus afectos. Efectos que podemos caracterizar en diferentes categorías:

a) Efectos descriptivos mediante los cuales observamos el avance de las aguas del río ya por la utilización de tiempos verbales que así lo expresan, ya por la introducción de puntos de referencias específicos:

A la hora que me fui a asomar, el río ya había perdido sus orillas. Iba subiendo poco a poco por la calle real, y estaba metiéndose a toda prisa en la casa de esa mujer que le dicen la «Tambora».

Y por el otro lado, por donde está el recodo, el río se debía de haber llevado, quien sabe desde cuando, el tamarindo que estaba en el solar de mi tía Jacinta. . . y por eso no más la gente se da cuenta de que la creciente esta que vemos es la más grande de todas las que ha bajado el río en muchos años ${ }^{10}$.

En el primer párrafo se nos presenta la crecida de las aguas en relación con la casa de la «Tambora». La utilización aquí de la perífrasis verbal en gerundio nos ofrece la idea de esta progresión. En el segundo, el punto de referencia es el tamarindo que al no existir denotaba a la gente del pueblo la fuerza de la crecida.

\footnotetext{
${ }^{5}$ Donald K. Gordon, Los cuentos de Juan Rulfo (Madrid: Colección Nova Scholar, 1976), pp. 182-183.

${ }^{6}$ Juan Rulfo, El llano en llamas (México: Fondo de Cultura Económica, 1964), p. 31.

${ }^{7}$ Ibid., p. 33.

${ }^{8}$ Ibid., p. 34.

${ }^{9}$ Ibid., p. 34.

${ }^{10}$ Ibid., p. 32.
} 
b) Efectos sonoros:

El estruendo que traía el río al arrastrase me hizo despertar en seguida a pegar un brinco de la cama con mi cobija en la mano, como si hubiera creído que se estaba derrumbando el techo de mi casa.

Cuando me levanté, la mañana estaba llena de nublazones y parecía que había estado lloviendo sin parar. Se notaba en que el ruido del río era más fuerte y se oía más cerca ${ }^{11}$. ...pues abajo, junto al río hay un gran ruidazal y sólo se ven las bocas de muchos se se abren y se cierran y como que quieren decir algo, pero no se oye nada ${ }^{12}$.

El hombre aquí se encuentra mudo, fundido en la inmensidad sonora que le rodea.

c) Efectos olfativos de los que obtenemos el ambiente hediondo que acompañaba a la inundación: «Se olía como se huele una quemazón, el olor a podrido del agua revuelta ${ }^{13}$. Efectos enfatizados por la utilización reiterativa del verbo oler tanto en su forma verbal -«olía», «huele»- como sustantivada.

d) Efectos de color: «Mi hermana y yo volvíamos a ir por la tarde a mirar aquel amontonadero de agua que cada vez se haca más espesa y oscura y que pasa ya muy por encima de donde debe estar el puente ${ }^{14}$. La impresión de oscuridad conlleva unas connotaciones que nos guían a un terreno simbólico: resultado moral de este destrozo físico ocasionado por las aguas.

Por otro lado, y a un nivel simbólico, observamos la descripción de los sentimientos de Tacha en relación misma con los efectos que la subida del río estaba produciendo:

Y Tacha llora al sentir que su vaca no volverá porque la ha matado el río. Está aquí, a mi lado, con su vestido color rosa, mirando el ró desde la barranca y sin dejar de llorar. Por su cara corren chorretes de agua sucia como si el río se hubiera metido dentro de ella ${ }^{15}$.

Tacha parece presentirque su vida va a cambiar desde ahora. El río simbólicamente se funde con Tacha con resultados catastróficos para la muchacha. Utilizándose además, en la identificación Tacha-río, elementos ya descritos en relación con el plano literal del río; es decir, efectos sonoros y olfativos:

... De su boca sale un ruido semejante al que se arrastra por las orillas del río, que le hace temblar y sacudirse todita, y, mientras, la creciente sigue subiendo. El sabor a podrido que viene de ella salpica la cara mojada de Tacha y los dos pechitos de ella

\footnotetext{
${ }^{11}$ Ibid., p. 31.

12 Ibid., p. 32.

${ }^{13}$ Ibid., p. 31.

${ }^{14}$ Ibid., p. 32.

${ }^{15}$ Ibid., p. 35.
} 
se mueven de artiba abajo, como si de repente comenzaran a hincharse para empezar a trabajar por su perdición ${ }^{16}$.

El río, la naturaleza hostil es la que, con una fuerza que podríamos llamar demoníaca, origina la destrucción moral de Tacha y las esperanzas de salvación que para elle tenía su familia.

«La Cuesta de las Comadres» es, como «Es que somos muy pobres», un monólogo en donde se narra la adversión recíproca de los pueblos vecinos Zapothán y la Cuesta de las Comadres, pueblo último amenazado por los hermanos Odilón y Remigio Torrico, y el asesinato de éste a manos del propio narrador: «A Remigio Torrico yo lo maté» ${ }^{17}$.

Aquí el agua se presenta bajo la reiteración constante y violenta de la lluvia, y su transformación en heladas, como causa primaria de la despoblación paulatina de la Cuesta de las Comadres. El narrador nos describe el efecto de la lluvia sobre la tierra: «El lugar no era feo; pero la tierra se hacía pegajosa desde que comenzaba a llover, y luego había un desparramero de piedras duras y filosas como troncones que parecían crecer con el tiempo» ${ }^{18}$. La naturaleza había ido cercando progresivamente a este lugar con su hostilidad: «El vientò que atravesaba los cerros era más frío que otras veces; pero no se sabía por qué, todos allí decían que hacía muy buen tiempo» ${ }^{19}$. Hasta que finalmente llegaron las heladas:

Primero se habían ido de uno en uno; pero los últimos casi se fueron en manada. Ganaron y se fueron, aprovechando la llegada de las heladas. En años pasados llegados las heladas y acabaron con las siembras en una sola noche. Y este también. Por eso se fueron. Creyeron seguramente que el año siguiente sería los mismos y parece que ya no se sintieron con ganas de seguir soportando las calamidades de tiempo todos los años y las calamidades de los Torricos todo el tiempo ${ }^{20}$.

Sin embargo, es la imposibilidad de luchar en contra de la naturaleza lo que les hace huir. Razón incluso más poderosa que le amenza de los Torricos, ya que como nos dice el narrador: «La cosa es que todavía después de que murieron los Torricos nadie volvió más por aquí. Yo estuve esperando. Pero nadie regresó» ${ }^{21}$. La gente se había marchado pero la naturaleza indiferente seguía su eterno rotor: «Los únicos que no dejaron nunca de venir fueron los aguaceros de mediados de año, y esos ventarrones que soplan en Febrero y que le vuelan a uno la cobija a cada rato» ${ }^{22}$.

\footnotetext{
${ }^{16}$ Ibid., p. 36.

${ }^{17}$ Ibid., p. 26.

${ }^{18}$ Ibid., p. 22.

${ }^{19}$ Ibid., p. 26.

${ }^{20} \mathrm{Ibid}$.

${ }^{21}$ Ibid., p. 22.

22 Ibid., p. 23.
} 
Se nos presenta aquí un pueblo rodeado, en contraste con Luvina, por los efectos constantes y reiterativos de la lluvia. Elemento también presente en el asesinato del arriero por los hermanos Torricos. Así nos los cuenta el narrador:

Fue como a mediados de las aguas cuando los Torricos me convidaron para que les ayudara a traer unos tercios de azúcar. Yo iba un poco asustado. Primero, porque estaba cayendo una tormenta de esas en que el agua parece escarbarle a uno debajo de los pies. Después, porque no sabía adonde iba. De cualquier modo, allívi yola señal de que no estaba ya para andar en andanzas ${ }^{23}$.

Elnarrador se nos presenta como un personaje elemental, sin conflictos interiores, indiferente como el propio paisaje. Así nos dice, explicando fríamente, el modo en que mató a Remigio Torrico:

Entonces vi que se le iba entristeciendo la mirada como si comenzara a sentirse enfermo. Hacía mucho que no me tocaba ver una mirada así de triste y me entró la lástima. Por eso aproveché para sacarle la aguja de arria del ombligo y metérsela más arribita, allí donde pensé que tenía el corazón. Y sí, allí lo tenía porque no más dio dos o tres respingos como un pollo descabezado y luego se quedó quieto ${ }^{24}$.

Hombre, tanto en este cuento como en la generosidad de los cuentos de Rulfo, arraigado a la tierra. Arraigo que no es otra cosa que cordón umbilical ${ }^{25}$.

En «El hombre» se utiliza uno de los métodos narrativos más complicados de Rulfo, «el cuento organizado omnisciente por el autor, el cuento que se mueve en planos diferentes pero simultáneos con personajes que revelan su personalidad y la personalidad de cada uno a través de monólogos interiores» ${ }^{26}$.

Los incidentes del cuento son sencillos, José Alcancía, vengando la muerte de su hermano, había matado a la mujer e hijos de Urquidi. Urquidi, por esta razón, le persigue hasta darle muerte. La persecución tiene lugar en las cercanías de un río al que José alcancía quiere llegar esperando salvarse. Las imágenes utilizadas en la descripción del río nos reflejan la sensación de incertidumbre y amenaza que embarga a José Alcancía en su huida. El narrador nos cuenta: «Soltó el machete que llevaba todavía apretado en la mano cuando el frío te entumeció las manos. Lo dejó allí. Lo vio brillar como un pedazo de culebra sin vida, entre espigas secas» ${ }^{27}$. El elemento comparativo, «culebra», utilizado en la descripción del machete, reaparece líneas más adelante, aplicado al movimiento del río:

${ }^{23}$ Ibid., p. 24-25.

${ }^{24}$ Tbid., p. 29.

${ }^{25}$ Manuel A. Senar-Maytonera, «El hombre y el paisaje del campo jalisciense en «La Cuesta de las Comadres», cuento de Juan Rulfo, «Cuademos Americanos, vol. 177 (Julio-Diciembre, 1971). p. 213.

${ }^{26}$ Gordon, Los Cuentos, p. 161.

${ }^{27}$ Rulfo, El llano, p. 39. 
Muy abajo el río corre mullendo sus aguas entre sabinos florecidos; meciendo su espesa corriente en silencio. Camina y da vueltas sobre sí mismo. Va y viene como una serpentina enroscada sobre la tierra verde. No hace ruido ${ }^{28}$.

Aunque aquí, la sensación de peligro aumenta. La comparación «como una serpentina enroscada sobre la tierra verde», en un ambiente de silencio total, nos presenta la idea de este reptil no sólo vivo, sino en posición de acecho. Y de nuevo se nos dice: «El hombre encontró la línea del río por el color amarillo de los sabinos. No lo oía. Sólo lo veía retorcerse bajo las sombras ${ }^{29}$. En estas palabras se continúa la comparación del río con una serpiente mediante el uso de «retorcerse». La sensación implícita de peligro no pasa inadvertida por el hombre: «Caminaré más abajo. Aquí el río se hace un enredijo y puede devolverme a donde no quiero regresar» ${ }^{30} ;$ ni tampoco para su perseguidor: «Estás atrapado -dijo el que iba detrás de él que ahora estaba sentado a la orilla del río» ${ }^{31}$.

La percepción de peligro aumenta cuando la descripción del río aparece más cerca a nuestro sentidos:

El río en estos lugares es ancho y hondo y no tropieza con ninguna piedra. Se resbala en un cauce como de aceite espeso y sucio. Y de vez en cuando se traga alguna rama en sus remolinos, sorbiéndola sin que se oiga ningún quejido ${ }^{32}$.

Esta sensación viene de la comparación del cauce con «aceite espeso y sucio» y el efecto del remolino que se «traga» alguna rama «sorbiéndola» sin que oiga ningún «quejido». El río está descrito de una manera hostil, yo diría que hasta cruel, como casi todos los aspectos de la naturaleza presentados por Rulfo.

Lo sucedido tras esta persecución lo sabemos por un pastor que cuenta a la autoridades el hallazgo de un cadáver al lado del río. Aquí la descripción del río ocupa un segundo lugar:

Lo vi desde que se zambulló en el río. Apechugó el cuerpo y luego se dejo ir corriente abajo, sin manotear, como si caminara pisando el fondo. Después rebalsó la orilla y puso sus trapos a sacar. Lo vi que temblaba de frío. Hacía aire y estaba nublado ${ }^{33}$.

Pero la hostilidad del río persiste:

\footnotetext{
${ }^{28}$ Ibid.

${ }^{29}$ Ibid.

${ }^{30}$ Ibid., p. 41.

${ }^{31}$ Ibid., p. 42.

${ }^{32}$ Ibid.

${ }^{33}$ Ibid., p. 43.
} 
Lo vi beber agua y luego hacer buches como quien está enjuagándose la boca; pero lo que pasaba era que se había tragado un buen puñado de ajolotes, porque el charco donde se puso a beber estaba plagado de ajolotes ${ }^{34}$,

hasta que el hombre encuentra allí su muerte:

Primero cré que se habfa doblado al empinarse sobre el río y no se habfa podido ya enderezar la cabeza y que luego se había puesto a resollar agua, hasta que le vi la nuca repleta de agujeros como si lo hubieran taladrado ${ }^{35}$.

La muerte ya se nos estaba aventurando por el conjunto de imágenes. Y así también lo preconizaba su propio perseguidor: «Se arrodillará y me pedirá perdón. Y yo le dejará ir un balazo en la nuca. .. Eso sucederá cuando yo te encuentre» ${ }^{36}$.

En «El Paso del Norte», el río tiene un funcionamiento muy similar. Este cuento, cuya técnica narrativa es el diálogo, nos presenta la condición del campesino pobre que ha dejado a su mujer e hijos en manos de su padre para ir a Estados Unidos en donde pretende hacer fortuna. Pero el hijo, único superviviente de un grupo de hombres como él, eś herido al pasar el río que lo conduciría a la tierra prometida.

Otra vez, como en «El hombre», aunque descrito de una manera más objetiva, el río se muestra como un testigo de esta matanza que se infiere ha sido realizada por los apaches. El diálogo entre el padre y el hijo a la vuelta de este último, nos revela las circunstancias:

-Padre, nos mataron.

-¿A quienes?

-A nosotros. Al pasar el río. Nos zumbaron las balas hasta que nos mataron a todos. -¿En dónde?

-Allá, en el Paso del Norte, mientras nos encandilaban las linternas, cuando fbamos cruzando el río.

¿ ¿Y por qué?

-Pos no lo supe, padre ${ }^{37}$.

El río se muestra indiferente a lo que sucede a su alrededor. Así explica el hijo la muerte de su amigo Estanislao: «Y se murió en la orilla, frente a las luces de un lugar que le dicen Ojinaga, ya de este lado, entre los tules que siguieron peinando el río como si nada hubiera pasado ${ }^{38}$.

La indiferencia del río se utiliza en cierta manera también para definir una vida sin destino. Así dice el padre ante las quejas de su hijo: «Di que te fue bien y que conociste

${ }^{34}$ Ibid., p. 45.

${ }^{35}$ Ibid., p. 47.

${ }^{36}$ Ibid., p. 38.

${ }^{37}$ Ibid., pp. 123-124.

${ }^{38}$ Ibid., p. 124. 
mujer y tuviste hijos, otros ni siquiera eso han tenido en la vida, han pasado como las aguas de los ríos, sin comerse ni beberse ${ }^{39}$.

Y metafóricamente, el agua como elemento individualizado se utiliza para describir la acción de comer o gastar dinero: «Pero el dinero se acaba; vienen los hijos y se lo sorben como agua» ${ }^{40}$.

En estos dos últimos cuentos, la abundancia de agua quizás no funcione en una hostilidad tan real o física como veíamos en «Es que somos muy pobres» $\mathrm{y}$ «La Cuesta de las Comadres», pero sin embargo, se transforma simbólicamente en un instrumento que aunque externo, no deja por ello de ser menos cruel e indiferente al destino del hombre.

\section{Falta de agua: «Nos han dado la tierra», «Luvina», «iDiles que no me maten!», «Talpa» $\mathbf{y}$ «No oyes ladrar los perros»}

En «Nos han dado la tierra», «Luvina» y « ¿Diles que no me maten!», el agua, en su ausencia, se nos presenta como elemento causante de la angustia, la desesperación e incluso de la muerte.

En «Nos ha dado la tierra» se narra la frustración de unos hombres a los que el gobierno ha dotado de una tierra, árida y seca, localizada en El Llano Grande. En «Luvina», la falta de agua llega a tal límite que hasta casi desaparece la explicitación del vocablo. El viento domina en este cuento, vive día a día con los habitantes del pueblo y hasta llega a formar parte del paisaje como uno más de ellos. Amparo Dávila nos dice a este respecto: «Pinos, el pueblo donde nací, es el pueblo de las mujeres enlutadas de Agustín Yáñez, es también Luvina donde sólo se oye el viento de la mañana a la noche» ${ }^{1}$. Sin embargo, al terminar de leer «Luvina», lo que nos queda, incluso más que los efectos del viento, es un sentimiento irreprimible de sequedad en la garganta. Hasta «el rocío se cuaja en el cielo antes de que llegue a caer sobre la tierra» ${ }^{2}$.

En «iDiles que no me maten!», la naturaleza se presenta de igual manera hostil. Aquí, a causa de una sequía, Juvencio Nava, con el fin de poder alimentar a sus animales, había tenido que matar a Lupe Terreros que le negaba el pasto. Treinta y cinco años después de su asesinato, Juvencio, ya viejo, cuando su cuerpo era «un puro pellejo correoso curtido por los malos días en que tuvo que andar escondiéndose de todo ${ }^{3}$, iba a morir a manos de uno de los hijos de Lupe Terreros. Quizás, el énfasis de este cuento está, observando su estructura reiterativa, en ese agarrarse desesperadamente a la vida que embargo a Juvencio: «le habían entrado unas ganas tan grandes de vivir como sólo

\footnotetext{
${ }^{39}$ Ibid., p. 121.

${ }^{40}$ Ibid.

${ }^{1}$ Rafael Solana et al., Los narradores ante el público (México: Editorial Joaquín Mortiz, 1966), p. 127.

${ }^{2}$ Juan Rulfo, El llano en llamas (México: Fondo de Cultura Económica, 1964), p. 96.

${ }^{3}$ Ibid., p. 80.
} 
las puede sentir un resucitado» ${ }^{4} ;$ pero hemos de considerar que estas ansias de vida no son sino una consecuencia directa de su crimen a causa de la sequía junto con un poderoso deseo de salvar a su animales:

Don Lope Terreros, el dueño de la Puerta de Piedra, por más señas su compadre. Al que él, Juvencio Nava, tuvo que matar por eso; por ser el dueño de la Puerta de Piedra y que, siendo también su compadre, le negó el pasto para sus animales 5 .

En los tres cuentos se plantea la introspección hacia un yo interno, ese encerramiento del hombre en sí mismo, en comunicación externa solamente con la naturaleza. Una naturaleza, como hemos especificado, hostil, que no remite posibilidades de futuro.

No hay futuro para estos hombres. Luvina se nos aparece como un pueblo condenado por su medio ambiente. «Desde el principio de la narración, con segura mano, nos lleva Rulfo hacia un tiempo irreal, un tiempo que según avanza, vemos que se ha quedado quieto dentro de un alguien, muerto» ${ }^{6}$. El tiempo, inmóvil, no llega a traspasar la barrera del futuro porque en Luvina el futuro no existe.

«¡Diles que no me maten!» también plantea en este sentido el retorno de la sequía. La áfianzación de los medios físicos siempre tan adversos para el hombre y que le obligan a vivir día a día, sin un mañana: «Ya era tiempo de que hubieran venido las aguas y las aguas no aparecían y la milpa comenzaba a marchitarse. No tardaría en estar seca de todo»?

De la misma manera sucede en «Nos han dado la tierra». No existe esperanza de que llueva en El Llano. Con razón Donald Gordon ${ }^{8}$ la ha comparado con la Comala de Pedro Páramo: «Con todo, yo sé que desde que era muchacho no vi llover nunca sobre el llano, lo que se llama llover»?

En Luvina, la lluvia, tan escasas, cuando aparece, irónicamente en vez de beneficiar a la tierra, la destruye más si es que ello fuera posible:

Allá llueve poco. A mediados de año llegan unas cuantas tormentas que azotan la tierra y la desgarran, dejando nada más el pedregal flotando encima del tepetate. Es bueno entonces ver como se arrastran las nubes... Pero después de diez o doce días se van y no regresan sino al año siguiente, $y$ a veces se da el caso de que no regresan en varios años.

Si, llueve poco. Tan poco o casi nada, tanto que la tierra, además de estar reseca y achicada como cuero viejo, se ha llenado de rasjaduras y de esa cosa que allí llaman «pasojos de agua», ... ${ }^{10}$.

\footnotetext{
${ }^{4}$ Tbid., p. 86.

${ }^{5}$ Ibid.

${ }^{6}$ Blanco Aguinaga, «Realidad y estilo», p. 88.

${ }^{7}$ Rulfo, El llano, p. 90.

${ }^{8}$ Gordon, Los cuentos, p. 61.

${ }^{9}$ Rulfo, El llano, p. 16.

${ }^{10}$ Ibid., p. 96.
} 
Esta ironía sórdida aparece también en «Nos han dado la tierra»:

Cae una gota de agua, grande, gorda, haciendo un agujero en la tierra y dejando una plasta como la de salivazo. Cae sola. Nosotros esperamos que sigan cayendo más y las buscamos con los ojos. Pero no hay ninguna más. No llueve... Y la gota caída por equivocación se la come la tierra y desaparece en su sed" ${ }^{11}$.

Una sola gota cae. Y la tierra personalizada, haciéndose una con el hombre, fundiéndose con él, y también con una sed monstruosa «se la come».

La ironía en «¡Diles que no me maten!» adquiere un sentido delirante y fatal para el protagonista. Juvencio es el personaje que más nos presenta la fusión con la tierra:

Sus ojos se habían apeñuscado con los años, venfan viendo la tierra, aqứ, debajo de sus pies, a pesar de la oscuridad. Allí en la tierra estaba su vida. Sesenta años de vivir sobre ella, de encerrarla entre sus manos, de haberla probado como se prueba el sabor de la carne ${ }^{12}$.

Palabras en las que incluso encontramos una metáfora de orden mineral, aplicada a los ojos, «apeñuscados». Sus ojos se habían convertido en peñuscos de tanto mirar la tierra, de tanto vivir la tierra. Ese amor a todo lo que el concepto tierra encerraba para él le había fatalmente perdido hacía treinta y cinco años, y le iba, irónicamente, a perder de nuevo:

Les había visto con tiempo. Siempre tuvo la suerte de ver con tiempo todo. Pudo haberse escondido, caminar unas cuantas horas por el cerro mientras ellos se iban y después volver a bajar. Al fin y al cabo la milpa no se lograría de ningún modo. Ya era tiempo de que hubieran venido las guas y las aguas no aparecían y la milpa comenzaba a marchitarse. No tardaría en estar seca del todo ${ }^{13}$.

Juvencio había visto unos hombres pisando la milpa y había ido a avisarles de que ésta estaba comenzando a creer sin percatarse que estaba condenada a marchitarse de todo modos. Estos hombres venían buscándole a él.

Además de este nivel irónico, y sin total exclusión del mismo, podemos identificar en estos tres cuentos un funcionamiento perfectamente contractivo alrededor de la conceptualización hecha del agua. Este funcionamiento consiste en la presentación al lado de un paisaje seco, con total ausencia de agua, identificado siempre con los personajes, otro con abundancia de agua, que contribuye a aumentar con su efecto, la sensación de sequedad y la situación ya de por sí desesperada de los personajes. En «Diles que no me maten!», este funcionamiento no es tan redundante como en «Luvina» $y$ «Nos han dado la tierra», pero no por ello menos trágico y efectivo. Las tierras de Juvenio sufren la sequía con más rudeza que las de Lupe Terreros. Las yerba

\footnotetext{
${ }^{11}$ Ibid., p. 16.

${ }^{12}$ Ibid., p. 89.

${ }^{13}$ Ibid., p. 90.
} 
crece en las de este último, yerba que significa existencia de agua, aunque no se explicite de dónde, en contraposición con la sequedad total que conduce a Juvencio a una situación inaguantable:

Primero se aguantó por puro compromiso. Pero después, cuando la sequfa, en que vio como se morían uno tras otro sus animales hostigados por el hambre y que su compadre seguía negándole la yerba para sus potreros, entonces fue cuando se puso a romper la cerca y a arrear la bola de animales flacos hasta las paneras para que se hartaran de comer ${ }^{14}$.

En «Nos han dado la tierra», el contraste aparece en forma de tierra fértil, prohibida, al lado del río. La tierra, y de nuevo aquí la ironía grotesca, está muy cerca de la que les han dado. Así se expresan los hombres en presencia del delegado:

Nosotros paramos la jeta para decir que el llano no lo queríamos. Que queríamos lo que estaba junto al río. Del río para allá, por las vagas, donde están esos árboles llamados casuarinas y las paraneras y la tierra buena. No este duro pellejo de vaca que se llama El Llano ${ }^{15}$.

Deseo de lo que para ellos representa un paraíso, tan cercano y a la vez $\tan$ fuera de su alcance. La atribución, en oposición, a la tierra concedida de «duro pellejo de vaca», revela una sequedad absoluta.

El contraste mayor se manifiesta en el momento en el que tras el reconocimiento de El Llano, el grupo de hombres llega a las tierras fértiles, ansiadas:

Conforme bajamos, la tierra se hace buena. Sube polvo desde nosotros como si fuera un atajo de mulas lo que bajara por allí; pero nos gusta llenarnos de polvo. Nos gusta. Por encima del río, sobre las copas verdes de las casuarinas, vuelan parvadas de chachalacas verdes. Es también eso lo que nos gusta ${ }^{16}$.

En «Luvina», el agua, situándonos en los dos planos de la narración--presente/ pasado-- se presenta igual que en el cuento anterior, como un elemento de contraste intensificador a la vez de la exasperante sequedad y muerte que allí se respira. La descripción de Luvina, encauzada por un narrador en primera persona a un pasado indefinido, se ve interrumpida varias veces por la voz de otro narrador en tercera persona que nos va mostrando un contraste, en un presente actual, que resulta irónicamente cruel:

Hasta ellos llegaban el sonido del río pasando sus crecidas aguas por las ramas de los camichines, el rumor del aire moviendo suavemente las hojas de los almendros, y los gritos de los niños jugando en el pequeño espacio iluminado por la luz que salfa de la tienda ${ }^{17}$.

\footnotetext{
${ }^{14}$ Ibid., pp. 86-87.

${ }^{15}$ Ibid., p. 17.

${ }^{16}$ Ibid., p. 20.

${ }^{17}$ Ibid., p. 95.
} 
Este es un lugar en el que sí hay agua, donde el viento es suave, en donde existen niños, y por tanto, vida, posibilidad de futuro. En Luvina no hay niños, «los niños que han nacido allí se han ido... Apenas les clarea el alba y ya son hombres» ${ }^{18}$. Los elementos que se observan aquí se pueden contrastar uno a uno con los ofrecidos en la descripción de Luvina.

Esta interrupción de la voz del narrador en tercera persona se realiza varias veces y nos va enmarcando progresivamente el monólogo del personaje central en un nivel tanto contrastivo como temporal: «Allá fuera seguía oyéndose el batallar del río. El rumor del aire. Los niños jugando. Parecía ser aún temprano, en la noche» ${ }^{19}$. Un lenguaje formado de frases cortas para darnos, con toda claridad, los tres elementos más destacados del contraste: río, viento como un rumor, no ese viento pardo de Luvina; y los niños. Así como la indicación temporal: «Parecía ser aún temprano, en la noche».

Al final del cuento se nos define de nuevo esta progresión cronológica, utilizando reiterativamente los elementos contrastivos que observábamos. El narrador ha seguido contando a su silencioso oyente su pasado en Luvina por muchas horas. El tiempo sí existe en este pueblo, en Luvina, como antes veíamos, el tiempo parecía haberse detenido:

Afuera seguía oyéndose como avanzaba la noche. El chapoteo del río contra los troncos de los camichines. El griterío ya muy lejano de los niños. Por el pequeño cielo de la puerta se asomaban las estrellas.

El hombre que miraba a los comejones se recostó sobre la mesa y se quedó dormido ${ }^{20}$.

Rulfo llevará esta estructura contractiva de igual manera a Pedro Páramo, aunque en el caso de esta novela, el pasado representa lo paradisíaco, en oposición con un presenta muerto. «Luvina», como nos dice Rodríguez Alcalá, «es un cuento que prefigura el de una novela: el pueblo de Comala. Pero Comala no fue siempre un lugar atroz como Luvina, como San Juan de Luvina que ha sido siempre el Purgatorio. Comala fue un tiempo el Paraíso. Sólo después de muchos males se hizo peor que Luvina: se convirtió en el Infierno» ${ }^{21}$.

El agua se utiliza por otra parte con un sentido simbólico, no por ello menos real, al ser asociada con funciones propias del organismo humano. Este sentido tiene a su vez la facultad de definir aún más la identificación del hombre con el paisaje. En «Es que somos muy pobres», «El hombre» y «Paso del Norte» ya habíamos observado un cierto nivel de este simbolismo. En «Luvina», éste alcanza extremos angustiosos: «Malo cuando deja de hacer aire. Cuando esto sucede, el sol se arrima mucho a Luvina y nos chupa la sangre y la poca agua que tenemos en el pellejo. El aire hace que el sol se esté allá arriba» ${ }^{22}$. El hombre puede seguir su mismo camino si «deja de hacer aire». El sol

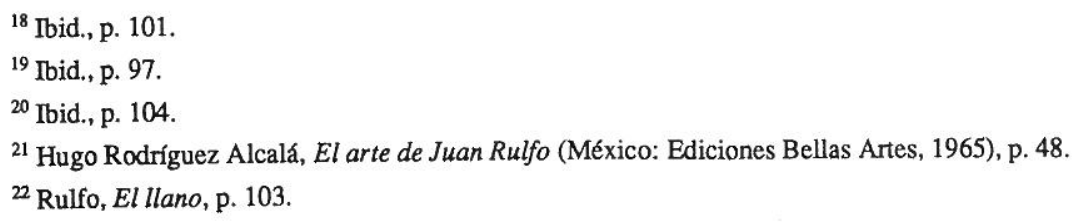


se presenta con características de un animal violento, capaz de destruir al hombre. El viento, paradójicamente, actúa como elemento catalizador entre el sol y la casi absoluta falta de agua para la tierra y, por consiguiente, para el hombre; sentido que aparece en «Nos han dado la tierra»: «hasta las palabras se calientan en la boca con el calor de afuera, y se le resecan a uno en la lengua hasta que acaban con el resuello» ${ }^{23}$.

En «iDiles que no me maten!», el agua sirve para expresar trágicamente, la intensidad de los sentimientos de Juvencio ante la muerte, sentimientos que llegan a ser algo casi físico:

Comenzó a sentir esa comezón en el estómago, que le llegaba de pronto siempre que veŕa de cerca la muerte y que le sacaba el ansia por los ojos, y que le hinchaba la boca de agua agria que tenía que tragarse sin querer ${ }^{24}$.

El agua aquí existe pero es «agria», no sacia la sed y aumenta el dolor interno de Juvencio.

Los personajes centrales de estos cuentos, excepto Juvencio, reconocen la imposibilidad de luchar en contra de todas las adversidades que la naturaleza les preserita. En «Nos ha dado la tierra», los hombres se había ido «desperdigando hasta no quedar más que un nudo» ${ }^{25}$. Cuatro hombres quedan nada más. Estos tampoco aceptarán la tierra concedida por el gobierno. La lejanía en la que el narrador nos sitúa El Llano nos lo indica: «La tierra que nos han dado está arriba» ${ }^{26}$. El retorno se plantea difícil.

El narrador en «Luvina» huye, quizás un poco tarde, cuando ya no es capaz de borrar de su mente las imágenes del pueblo, pero huye. Quedan allí los habitantes de Luvina, pero éstos ya han perdido toda capacidad de iniciativa. Tenían que estar allí porque no podían llevarse a sus muertos. Juvencio es el único que plantea una lucha abierta y lo que consigue es su autodestrucción.

El sentido simbólico del agua reaparece también en «Talpa», asociado a la enfermedad de Tanilo, tanto en el comienzo de ésta,

Desde hacfa años. Desde aquel día en que amaneció con unas ampollas moradas repartidas en los brazos y las piernas. Cuando después las ampollas se le convirtieron en llagas por donde no salía nada de sangre y sí una cosa amarilla como goma de copal que destilaba agua espesa ${ }^{27}$,

como al final, tras su muerte:

Y por aqư y por allá todas sus llagas goteando un agua amarilla, llena de aquel olor que se derramaba por todos lados y se sentfa en la boca, como si estuviera saboreando una miel espesa y amarga que se derretía en la sangre de uno a cada bocanada de aire ${ }^{28}$.

\footnotetext{
${ }^{23}$ Ibid., p. 10.

${ }^{24}$ Ibid., p. 89.

${ }^{25}$ Ibid., p. 15.

${ }^{26}$ Ibid., p. 20.

${ }^{27}$ Ibid., p. 56.

${ }^{28}$ Ibid., p. 65.
} 
El agua adquiere en estas dos citas anteriores, una capacidad de expresión poco menos que escalofriante.

Tanilo confiaba en la virgen de Talpa para su curación. Y es aquí de nuevo la utilización del agua, ahora en forma de lluvia, para describir, comparativamente, los poderes curativos de la virgen:

La virgencita le daría el remedio para aliviarse de aquellas cosas que nunca se secaban. Ella sabía hacer eso, ponerlo todo de nueva cuenta como un campo recién llovido. Ya alli, frente a Ella, se acabarían sus males. Eso pensaba él ${ }^{29}$.

La lluvia, en un sentido, prefigura su importancia para el campesino así como su ansia de poseerla, «como un campo recién llovido», y también, al mismo tiempo, es un cruel elemento de contraste con la realidad, con el sol y la sequedad en las condiciones casi infrahumana que les rodea en su peregrinación a Talpa:

Nunca había sentido que fuera más lenta y violenta la vida como caminar sobre un amontonadero de gente; igual que si fuéramos un hervidero de gusanos apelotonados bajo el sol, retorciéndonos entre la cerrazón del polvo que nos encerraba a todos en la misma vereda y nos llevaba como acorralados. Los ojos seguran la polvareda; daban en el polvo como si tropezaran contra algo que no se podía traspasar ${ }^{30}$.

Sólo a veces, la presencia del río las aliviaba, pero poco después todo volvía al infierno anterior:

Sólo a veces, cuando cruzábamos algún río, el polvo era más alto y más claro. Zambullíamos la cabeza acalenturada y renegrida en el agua verde, y por un momento de todos nosotros salía un humo azul, parecido al vapor que sale de la boca con el frío. Pero poquito después desaparecíamos otra vez entreveradas en el polvo, cobijándonos unos a otros del sol, de aquel calor del sol repartido entre todos ${ }^{31}$.

Pero Tanilo, como sabemos, a pesar de su confianza en la virgen, muere:

Porque la cosa es que a Tanilo Santos entre Natalia y yo lo matamos. Lo llevamos a Talpa para que se muriera. Y se murí́. Sabíamos que no aguantaría tanto camino; pero así y todo, lo llevamos empujándolo entre los dos, pensando acabar con él para siempre. Eso hicimos ${ }^{32}$.

El agua en «Talpa» no tiene la función trascendental que observábamos en los tres últimos cuentos, y tampoco la tiene en «No oyes ladrar los perros», cuyo papel se limita a la evocación.

\footnotetext{
${ }^{29}$ Ibid., p. 56.

${ }^{30}$ Ibid., p. 60.

${ }^{31}$ Ibid.

${ }^{32}$ Ibid., p. 55-56.
} 
Al principio, en la descripción del padre llevando a su hijo herido a Tanaya, se percibe un arroyo, pero a medida que la narración avanza, el paisaje se ha ido haciendo más árido. El agua, tan ansiosamente pedida por Ignacio, no tiene otra función que la de hacer recordar al padre un pasado lejano:

-Tengo sed.

-Peor para ti, Ignacio.

-Tengo sed.

-iAguántate! Ya debemos estar cerca...

-Dame agua.

-Aquí no hay agua. No hay más que piedras. Aguántate...

-Tengo mucha sed y mucho sueño.

-Me acuerdo cuando naciste. Así eras entonces. Despertabas con el hambre y comías para volverte a dormirte. Y tu madre te daba agua, porque ya te habías sacado la leche de ella. No tenías llenadero. Y eras muy rabioso. Nunca pensé que con el tiempo se te fuera a subir aquellas rabia a la cabeza... Tu madre, que descanse en paz, quería que te criaras fuerte... No tuvo más que a ti. El otro hijo que iba a tener la mató. Y tú la hubieras matado otra vez si ella estuviera viva a estas alturas ${ }^{33}$.

Tras recordar la niñez de Ignacio, seguidamente pasa al conflicto latente entre padre e hijo. Ignacio es un bandolero y ha deshonrado a su familia.

Ignacio, a pesar de los esfuerzos de su padre, llega ya muerto al pueblo:

Allí estaba ya el pueblo. Vio brillar los tejados bajo la luz de la Iưra. Tuvo la impresión de que lo aplastaba el peso de su hijo al sentir que las corvas se le doblaban en el último esfuerzo. Al llegar al primer tejabán, se recustó sobre el pretil de la acera y soltó el cuerpo, flojo, como si lo hubieran descoyuntado ${ }^{34}$.

\section{Conclusión}

El agua, en esta presentación tan particular del paisaje mexicano que realiza Juan Rulfo, adquiere una plurivalencia de significados y funcionamientos que nos subrayan su importancia tanto dentro de la vida de los personajes como en la técnica narrativa.

El anhelo del hombre por el agua visto en « $i$ Diles que no me maten!»y «Nos han dado la tierra», representa el anhelo mítico de la humanidad desde el origen de los tiempos. Sin embargo, la aparición del agua no se da con un total equilibrio pues en el caso de «Es que somos muy pobres» se presenta en forma de una inundación que destruye todos los bienes materiales de una familia y con ellos sus ilusiones para con su hija, o en «La cuesta de las Comadres» e incluso «Luvina», cuentos en los que la lluvia cae con tal violencia que destruye todavía más a la tierra.

\footnotetext{
${ }^{33}$ Ibid., p. 117-118.

${ }^{34}$ Ibid., p. 118.
} 
El agua, pues, condiciona al hombre y actúa como puente entre éste y su realidad exterior; puente que es «cordón umbilical», fusión del hombre con el paisaje hasta la desaparición de la distinción entre el uno y el otro.

Además, como los elementos componentes del paisaje descrito por Rulfo están siempre en una implacable hostilidad con el hombre, de esta fusión nace la angustia, la desesperación y la muerte.

En otros casos como «El hombre» o «Paso del Norte», el agua se presenta como algo más externo pero no por ello menos cruel e indiferente al destino del hombre.

La huida es posible pero no el enfrentamiento cara a cara. El enfrentamiento queda inconsciente, pegado al alma de cada uno. Quizás, aparte de los personajes en «Luvina» $\mathrm{y}$ «Nos han dado la tierra», el que mejor plantea este proceso cognoscitivo de la realidad es el protagonista de «Paso del Norte», que va buscando algo distinto, queriendo alejarse de la eterna pobreza del campesino; pero este hombre es herido precisamente al cruzar un río. Otros como él mueren dentro del mismo río, en la frontera entre un presente anónimo y un futuro prometedor.

No hay escapatoria para los personajes de los cuentos de Rulfo. La angustia se siente desde el caer torrencial de la lluvia o el desbordamiento salvaje de un río, hasta la «gota gorda» que la tierra sedienta se la «come».

Y es esta visión, este pesimismo absoluto de los personajes de Rulfo, incapaces de controlar sus vidas, siempre sometidos a una realidad exterior, a la realidad de un paisaje que les anula y extermina a cada momento, la que recorre toda la obra de Rulfo desde los cuentos de El llano en llamas, hasta su gran novela, Pedro Páramo.

\section{Bibliografía}

Blanco Aguinaga, Carlos. «Realidad y estilo de Juan Rulfo», En Nueva Novena Latinoamericana. pp. 85-171. Editado por Jorge Lafforge. Buenos Aires: Editorial Paidos, 1969.

Gordon, Donald K. Los Cuentos de Juan Rulfo . Madrid: Colección Nova Scholar, 1976. Langford, Walter M. The Mexican Novel Comes of Age. Indiana: University of Notre Dame Press, 1971.

Pupo-Walker, Enrique. «Personajes y ambientes en Pedro Páramo». Cuadernos Americanos 6 (Noviembre-Diciembre 1969), pp. 193-204.

Rodríguez Alcalá, Hugo. El arte de Juan Rulfo. México: Ediciones Bellas Artes, 1965. Rulfo, Juan. El llano en llamas. 6ª ed. México: Fondo de Cultura Económica, 1965. Serna-Maytonera, M. A. «El hombre y el paisaje del campo jalisciense en 'La Cuesta de las Comadres', cuento de Juan Rulfo». Cuadernos Americanos 177 (JulioDiciembre 1971), pp. 218-16.

Solana, Rafael, et. al. Los Narradores ante suPúblico. México: Editorial Joaquín Mortiz, 1966.

Xirau, Ramón. «Crisis del realismo». En América Latina en suLiteratura.,pp. 185-203. Editado por César Fernández Moreno. México: Siglo XXI, 1978. 